\title{
UDC: 004.652
}

DOI: 10.37128/2707-5826-2019-4-19 RISK CHARACTERIZATION IS THE FOURTH STAGE OF ECOLOGICAL RISK ASSESSMENT

V.V. MONARKH, Candidate of Agricultural Sciences, Senior Lecturer, Vinnytsia National Agrarian Universit

Risk values have been obtained using a situational risk model that enables to identify the storage buildings (objects) on the territories where special measures should be taken to reduce and eliminate pollution. The research results clearly prove availability of severe local sources of contamination of agricultural lands with organochlorine pesticides. There is a risk of contamination of other environmental objects with hazardous substances and a negative impact of toxic substances on human health. Migration of pesticides from the soil into agricultural products and drinking water has been identified.

The risk characterization stage assesses the frequency and magnitude of toxic effects, their reversibility or irreversibility. One of the methods used is the method of comparison of the results obtained with similar projects and studies. An important condition for the introduction into the general farming use of territories in the zones affected by the former pesticide and agrochemical storages in these settlements is the search for the methods of restoration and purification of soils of these territories from xenobiotics. Only after conducting the work on soil purification and availability of the inspection results showing positive changes, it will it be safe to grow agricultural products.

Keywords: obsolete pesticides, mathematical model, storage buildings, hazardous.

\section{Tabl. 2. Fig. 1. Lit. 12.}

Introduction. Production of high-quality agricultural production is possible on clean soil only. In Ukraine, areas around abandoned pesticide storehouses are still the main source of the pesticide soil pollution. These storehouses were used for a long time for storage of large quantities of pesticides. Most of pesticides that were stored in these storehouses are very dangerous. For example, there are 10 pesticides in the list of persistent organic pollutants (POPs) [1]. In USSR times, obsolete pesticides were accumulated in storehouses and scrapyards all around Ukraine. Spread of POPs into environment cause extreme danger for people and nature due to contamination of ground water, drinking water, plants and animal organisms. According to the Ministry of Ecology and Natural Resources of Ukraine, there are over 3000 pesticide storehouses situated on the territory of the country, not taking into account almost 2000 so-called "hot spots" - polluted sites of ruined storehouses. In 2010, The Ministry began implementing a major program aimed for hazardous waste disposal in Ukraine. This program is one of the most priority programs of the Ministry. Dangerous pesticides are transported for safe disposal to specialized factories outside of Ukraine due to lack of such factories on the territory of the country [2]. However, 
disposal of obsolete pesticides does not solve the problem of environmental pollution with pesticides. Due to long-term storage and usage of large quantities of pesticides, areas around pesticide storehouses are polluted with high concentrations of persistent toxic compounds. Pollution from such sources spread over the large distances [1], including nearby agricultural fields. This results the pollution of agricultural production. Usage of this production causes direct threat to the human organism [3, 12]. As we can see, there is an urgent need of cleaning of polluted soils in Ukraine. However, there are large numbers of different methods of soil cleaning that vary in cost, speed and efficiency. To solve the problem of choosing of the cleaning method, we use methods of ecological risk assessment to select the most efficient, environmentally safe and cheap method [4].

Materials and methods of research. The research was carried out on the territory of Kryzhopil region, Vinnytsia oblast. Analysis of the condition of pesticide storages was carried out on the basis of materials of the State Administration for Environmental Protection in Vinnytsia oblast as well as the results of the author's observations. Determination of pesticide residues in the soil, water and agricultural products within the limits of effects of former storages of unusable and forbidden pesticides was performed by HC-MS and HPLC-MC/MC methods using QuEChERS-method with the use of extraction, redistribution in acetonitrile and purification with dispersion TФE. The system 'Wolfram Mathematica 8' was used for mathematical calculations.

To estimate the risk for the territory with the obsolete pesticide storehouse, we have to know the total mass of POPs situated in the soil of the studied plot. We know that the highest concentration of PS is observed on the area around a storehouse. According to our previous researches, POPs concentration will decrease with the increase of the distance from the storehouse [4]. To determine the relationship between POPs concentration and distance from the storehouse, we use mathematical method of non-linear regression, namely, exponential regression [5-8]. To calculate the total mass of PS knowing relationship between PS concentration and the distance, we use practical aspects of theory of multiple integrals [9-10], and differential equations. To characterize the residual amount of pesticides in soil near pesticide warehouses, we studied organochlorine pesticide 4,4'-DDT and its metabolites (2,4DDT, 4,4'-DDE, 4,4'-DDD). Soil and plant sampling were conducted according to engineering specifications and state standards for Ukraine (ISO 10381, ISO 6498). Soil samples were taken using the method of compass point grid. Selection was conducted along four transects in each direction from a 28 Ecological Risks from Contamination of Ukrainian Soils by Persistent Organic Pollutants warehouse (north, south, east, and west). Six samples were collected on each transect at distances of 1 , 5, 10 and 15 meters from the warehouse. Soil was stored in paper bags prior to transfer to labeled plastic bags for transport to the laboratory. Soil samples were stored frozen until analysis. Sampled plants were carefully cleaned and separated into roots and shoots for analysis. Organochlorine pesticides were quantified by gas 
chromatography (GC) using an electronic-capture detector (ECD) according to accepted engineering specifications and state standards for Ukraine (ISO 10382, ISO 14181). Determination of pesticide concentration in soil took place in the Ecotoxicology department of the Institute of Agroecology and Environmental Economy UAAS. We estimate the risk of pollution of agricultural lands neighboring obsolete pesticides storehouses on four sites on the steppe territory of Ukraine. Google Maps software was used for sites area estimation. To process all formula and data calculations we used Wolfram Mathematica 8 [4].

Results and discussion. The risk characterization stage assesses the frequency and magnitude of toxic effects, their reversibility or irreversibility. One of the methods used is the method of comparison of the results obtained with similar projects and studies.

To calculate the environmental risks of contamination with organochlorine pesticides, there have been chosen agricultural lands bordering on the territories of former pesticide storages in Hariachkivka, Kisnytsia, Leonivka, and Zelenianka, where according to preliminary research different rates of contamination with certain toxicants have been established (Table 1).

The general formula for the situational risk model is:

$$
R=\frac{1}{2 I S C} \sum_{i}\left[A_{i}+B_{i}+D_{i}\right]
$$

Isc is a terrain-dependent index of soil self-purification;

$A_{i}$ - is the load of the $i^{\text {th }}$ pollutant by its impact on a human, i.e. how a certain pollutant will affect an individual during direct contact;;

$B_{i}$ is the load of the $i^{-{ }^{t h}}$ pollutant according to MAC, i.e. the impact of the contaminated site on the natural environment in the sense of risk;

$D_{i}$ is the load on the $i^{-{ }^{t}}$ pollutant according to the estimation of population edipcontacts, i. e. how the consumption of products grown on the contaminated site will affect the population.

To calculate block $\mathrm{A}_{i}$, it is necessary to calculate the value of $\mathrm{An}$, which is the mass of all active ingredient divided by the total area of influence of this active ingredient. To find An, a modified formula of direct load that takes into account the location of the storage nearby has been offered.

Based on the practical sections of the theory of differential equations [4], we assume that the pollution distributes around the storage in inverse exponential dependence on the distance. Then, given the methods of nonlinear regression [4], we can write the following formula:

$$
P_{i}(x)=P s_{i} \times l_{i} \times \operatorname{Exp}\left\{-m_{i} x+1\right\},
$$

where $P_{i}(x)$ is the concentration of the $i^{-{ }^{t h}}$ pesticide at a distance $x, P s_{i}$ is the contamination of the edaphotop of the storage by this pesticide, $\operatorname{Exp}\left\{-m_{i} x+1\right\}$ is the exponent, $l_{i}, m_{i}$ are regression coefficients (Wolfram Mathematica 8 was used to calculate them). 
Methods of practical aspects of multiple integrals have been applied to determine the total mass of active ingredient under known dependence of concentration on the distance to the storage [4]. Divide the area around the storage by concentric circles into sections. Number these sections in ascending order. Some of these sections will intersect with the territory of the field forming parts of the sectors of circles. Assume that $\mathrm{N}$ parts have been formed. The area of one such part can be calculated as follows:

$$
S_{k}=\pi \frac{\beta_{k}-\alpha_{k}}{2}\left(r_{k}^{2}-r_{k-1}^{2}\right),
$$

where $\alpha_{k}$ and $\beta_{k}$ are the starting and ending angles of the sector, respectively, $r_{k}$ is the radius of the $\mathrm{k}^{\text {th }}{ }^{\text {ch }}$ circle, $r_{k-1}$ is the radius of the $\mathrm{k}-1^{\text {st }}$ circle. We calculate the area (5) of all such parts as their sum:

$$
S=\sum_{k=1}^{N} S_{k}
$$

Dividing the field area like this, you can calculate the mass of substance by applying a double integral in polar coordinates.

Taking into account soil density $\theta$, the total mass of the active ingredient, which is distributed over the field, is calculated by the formula.

$$
\begin{aligned}
M_{i} & =\theta \sum_{k=1}^{N} \int_{\alpha_{k}}^{\beta_{k}} \int_{r_{k-1}}^{r_{k}} P_{i}(x) d x=\theta \sum_{k=1}^{N} \int_{\alpha_{k}}^{\beta_{k}} \int_{r_{k-1}}^{r_{k}} P s_{i} l_{i} \operatorname{Exp}\left\{-m_{i} x+1\right\} d x= \\
& =\theta \sum_{k=1}^{N}\left(\operatorname{Exp}\left\{-m_{i} r_{k-1}\right\}-\operatorname{Exp}\left\{-m_{i} r_{k}\right\}\right)\left(\beta_{k}-\alpha_{k}\right) \frac{P s_{i} l_{i} \operatorname{Exp}\{1\}}{m_{i}}
\end{aligned}
$$

Dividing $M$ - the total mass of the active ingredient by $S$ - the total area, we get a direct load of the $\mathrm{i}^{-{ }^{\text {th }}}$ pesticide, $\mathrm{kg} / \mathrm{ha}$. Having received this value, we can apply it to calculate the components of the situational risk model in the case of availability of edaphotop of the pesticide storage in the area investigated.

\begin{tabular}{|c|c|c|c|}
\hline Settlement (village) & Cropping area, ha & Pesticide & Direct load, kg/ha \\
\hline \multirow{2}{*}{ Hariachkivka } & \multirow[t]{2}{*}{41.98} & $\sum \mathrm{HCH}$ & 0.271368 \\
\hline & & $\sum \mathrm{DDT}$ & 0.149619 \\
\hline \multirow{2}{*}{ Kisnytsia } & \multirow[t]{2}{*}{89.90} & $\sum \mathrm{HCH}$ & - \\
\hline & & $\sum \mathrm{DDT}$ & 0.00958 \\
\hline \multirow{2}{*}{ Leonivka } & \multirow[t]{2}{*}{96.93} & $\sum \mathrm{HCH}$ & - \\
\hline & & $\sum \mathrm{DDT}$ & 0.2448 \\
\hline \multirow{2}{*}{ Zelenianka } & \multirow[t]{2}{*}{20.79} & $\sum \mathrm{HCH}$ & - \\
\hline & & $\sum \mathrm{DDT}$ & 4.06227 \\
\hline
\end{tabular}

Table 1

Direct pesticide load in the zones affected by former pesticide storages in Kryzhopil region, kg/ha

Source: based on own research 
It is estimated that the pesticide load per 1 ha of field in Zelenianka is 4.06227 $\mathrm{kg}$. Therefore, the reason for the significant contamination of beet samples with organochlorine pesticide residues $(0.42 \mathrm{mg} / \mathrm{kg})$ is quite clear. It is dangerous that the site, the soil of which is contaminated with hazardous pesticide residues, is private. The population growing agricultural products is at risk due to the systematic consumption of products contaminated with pesticides.

The table given above shows that the pesticide load per 1 ha of field in Kisnytsia is $9.5 \mathrm{~g}$. This amount of pesticide does not pose a significant hazard to agricultural lands and crop cultivation on the field. Agricultural lands of Hariachkivka and Leonivka should be considered hazardous. The load of the sum of DDT isomers and metabolites per 1 ha of field is 149 and 244 grams, respectively. In addition, in Hariachkivka, the soil is affected by contamination caused by another pesticide, namely, HCH. The load of HCH isomers per 1 ha of field is $271 \mathrm{~g}$. Thus, three settlements have agricultural lands located in the areas affected by the former pesticide storage are in the risk zone.

Taking into account the density of local soil $\left(1.650 \mathrm{t} / \mathrm{m}^{3}\right)$ and the index of selfpurification of the territory in oblast (for Vinnytsia oblast $I s c=0.61$ ), the components of the situational risk model have been calculated. The results of the calculations are presented in Table 8. Figure 6 shows the value of the situational risk rate for the selected sites. The control values are given according to [11].

Graduation of situational risk is expressed in terms of risk units, points $\left(R_{0}\right): R_{1}$ is low-risk (1-20), $R_{2}$ is moderate risk (20-40), $R_{3}$ is severe risk (40-60), and $R_{4}$ is high risk $(>60)$.

Table 2

The baseline model of situational hazard risk

\begin{tabular}{|c|c|r|r|r|}
\hline Settlement (village) & Pesticide & $\mathrm{A}_{i}$ & $\mathrm{~B}_{i}$ & $\mathrm{D}_{i}$ \\
\hline \multirow{3}{*}{ Hariachkivka } & $\sum \mathrm{HCH}$ & 28.4936 & 1.99315 & 93.1018 \\
\cline { 2 - 5 } & $\sum \mathrm{DDT}$ & 15.71 & 1.72344 & 44.3875 \\
\cline { 2 - 5 } & Total & 44.2036 & 3.71659 & 137.4893 \\
\hline \multirow{2}{*}{ Kisnytsia } & $\sum \mathrm{HCH}$ & - & - & - \\
\cline { 2 - 5 } & $\sum \mathrm{DDT}$ & 1.0059 & 0.9088 & 1.49864 \\
\hline \multirow{2}{*}{ Leonivka } & $\sum \mathrm{HCH}$ & - & - & - \\
\cline { 2 - 5 } & $\sum \mathrm{DDT}$ & 25.704 & 2.23759 & - \\
\hline \multirow{2}{*}{ Zelenianka } & $\sum \mathrm{HCH}$ & - & - & 24.287 \\
\cline { 2 - 5 } & $\sum \mathrm{DDT}$ & 426.538 & 3.522885 & 2.354 \\
\hline
\end{tabular}

Source: based on own research

According to the classification, the value of situational risk of soil contamination of the sanitary zone of the pesticide storage with the residues of $\mathrm{CO}$ pesticides in Zelenianka is high (4,650 points). In Hariachkivka, the value of situational risk is high both by the sum of HCH (203 points) and the sum of DDT (101 points). Despite insignificant soil contamination with pesticide residues around the pesticide storage, the value of situational risk has been high (200 points) in Leonivka, compared to other villages. Only in Kisnytsia, the value of situational risk is low (5 points). This 
let us argue that only in this settlement it is not obligatory to carry out surveys of the territory near the former storage with unusable pesticides before its introduction into general agricultural use. The farmlands and crops grown in these three settlements are at risk. There is a risk of contamination of the agroecosystem components with pesticide residues.

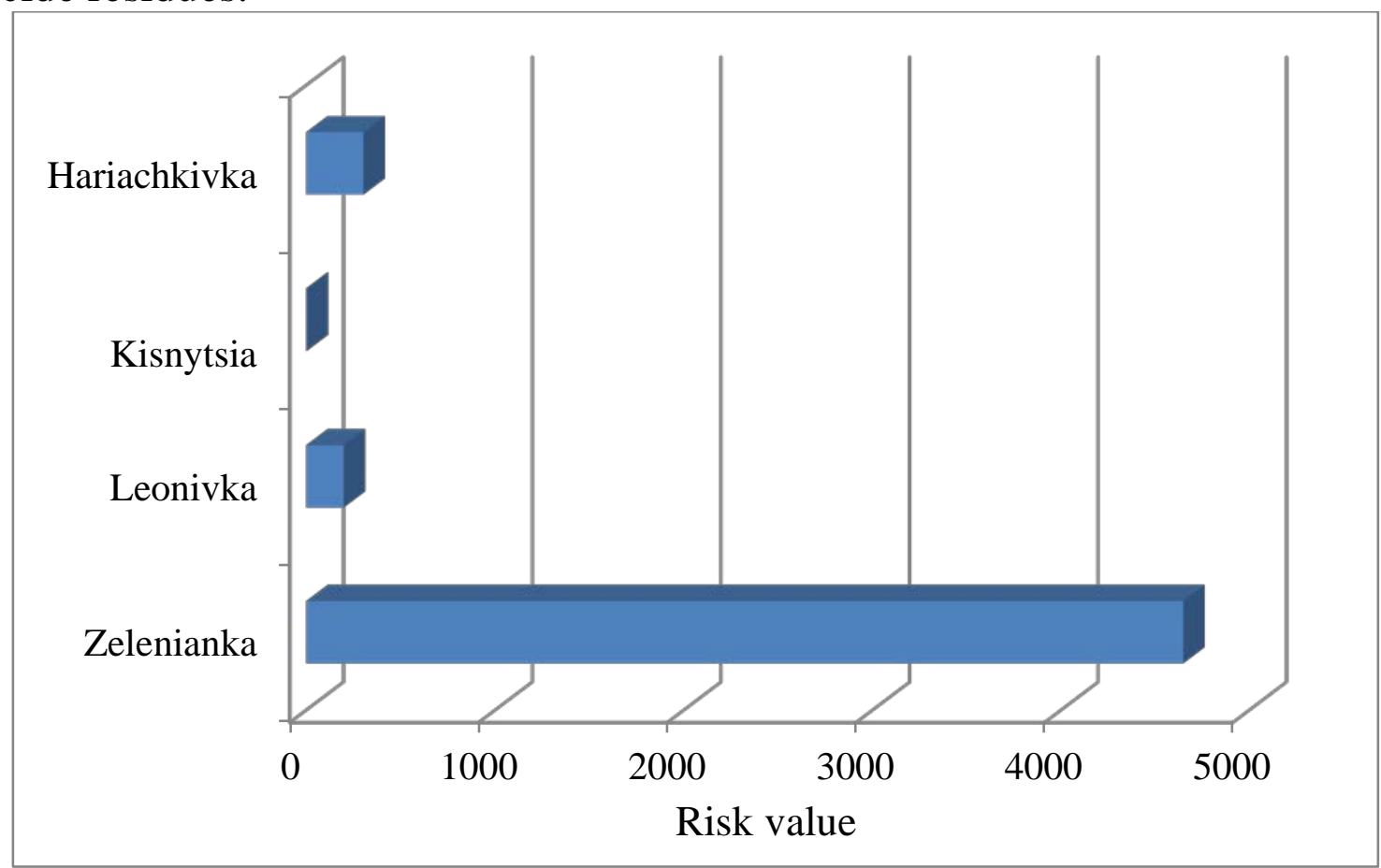

Fig. 1 Value of the situational risk of hazards

Source: based on own research

Taking the situational risk rate of 60 points that corresponds to high risks as $100 \%$, the situational risk for the settlements will be as follows: Hariachkivka 508\%, Leonivka - 333\%, and Zelenianka - 7,750\%. An important condition for the introduction into the general farming use of territories in the zones affected by the former pesticide and agrochemical storages in these settlements is the search for the methods of restoration and purification of soils of these territories from xenobiotics. Only after conducting the work on soil purification and availability of the inspection results showing positive changes, it will it be safe to grow agricultural products.

Conclusions. Risk value derived from the situational risk model has enabled us to identify the storages (sites), where special measures are needed to reduce and eliminate pollution. According to the gradation of the situational risk value, the risk value in Kisnytsia is low. Therefore, it is not necessary to propose soil purifying measures on this territory, since the former pesticide storage does not pose a threat to the environment. In Leonivka, Hariachkivka and Zelenianka, where the absolute risk value is highly hazardous and the soils of these territories are contaminated with persistent pesticides, soil restoration methods must be offered. There are two ways of dealing with contaminated soils, namely, conservation and purification.

Conservation requires high costs, and it is not always environmentally friendly, destroys soil structure and reduces its productivity. Preliminary calculations indicate 
the ability of pesticides to migrate in the soil profile up to a distance of $100 \mathrm{~m}$ from the storage (Hariachkivka and Zelenianka), so removal and disposal of contaminated soil layer from such sites is too expensive and impractical. The safest and most inexpensive method of soil restoration is biological purification of anthropogenically disturbed areas by plants.

\section{Список використаної літератури}

1. Стокгольмська конвенція про стійкі органічні забруднювачі, 2001. URL: http://www.ipen.org/ipenweb/firstlev el /pops.html.

2. Національний звіт про стан довкілля в Україні за 2011 рік. Міністерство екології та природних ресурсів України. Київ. ЛАТ-і-К. 2012.

3. Моклячук Л., Петришина В., Слободенюк О., Зацарінна Ю. Сталі стратегії фіторемедіації ділянок, забруднених застарілими пестицидами, екологічної та харчової безпеки та безпеки для Південно-Східної Європи та України. LLC. 2012. C. 81-89.

4. Моклячук Л., Дребот О., Моклячук О., Моклячук Т. Екологічні ризики від забруднення українських грунтів стійкими органічними забруднювачами. Дослідження довкілля та екологіï. 2014. № 2 (1). С. 27-34.

5.Моклячук Л., Городиська I., Слободенюк О., Петришина В., Фіторемедіація грунту, забрудненого застарілими пестицидами. Застосування фітотехнологій для очищення промислових, сільськогосподарських та очисних споруд. ТОВ. 2010. С. 113-124.

6. Єріна А.М. Статистичне моделювання та оцінки. Видавництво КНЕУ. Київ. 2001.

7. Bethea, R., Duran, B. \& Boullion, T. (1985) Statistical Methods for Engineers and Scientists. New York, USA". Marcel Dekker, Inc

8. Алексєєва I.B., Гайдей В.О., Діховичний О.О., Федорова Л.Б. Диференціальне обчислення функцій кількох аргументів. Визначені інтеграли. Диференціальні рівняння, публікація НТУУ “ КРI ". 2011.

9. Проданчук М., Великий В., Кучак Ю. Методологічні підходи до оперативно-екогігієнічної оцінки ареалу та обсягу використання пестицидів у сільському господарстві в Україні. Навколишнє середовище та здоров'я. 2003. № 1. C.75 - 78.

10. Алексєєва I.В., Гайдей В.О., Діховичний О.О., Федорова Л.Б. Диференціальне обчислення функцій кількох аргументів. Визначені інтеграли. Диференціальні рівняння, публікація НТУУ “ КРІ ". 2011.

11. Проданчук М., Великий В., Кучак Ю. Методологічні підходи до оперативно-екогігієнічної оцінки ареалу та обсягу використання пестицидів у сільському господарстві в Україні. Навколишнє середовище та здоров'я. 2003.

№ 1 . С.75 - 78 .

12. Соломон А.М., Віштак I.В., Войціцька О.М., Бондар М.М. Харчові добавки та їх функціональна роль. Збірник наукових праць ВНАУ.Аграрна наука та харчові технології. 2018. Вип. 4. С. 147-157. 


\section{Список використаної літератури у транслітерації / References}

1. Stokholmska konventsiia pro stiiki orhanichni zabrudniuvachi (2001). [Stockholm Convention on Persistent Organic Pollutants]. URL: http://www.ipen.org/ipenweb/firstlev el/pops.html [in Ukrainian].

2. Natsionalnyi zvit pro stan dovkillia v Ukraini za 2011 rik. Ministerstvo ekolohii ta pryrodnykh resursiv Ukrainy. [National report on the environmental state in Ukraine in 2011, Ministry of Ecology and Natural Resources of Ukraine (2012)]. Kiev, LAT-and-K. [in Ukrainian].

3. Mokliachuk L., Petryshyna V., Slobodeniuk O., Zatsarinna Yu (2012). Stali stratehii fitoremediatsii dilianok, zabrudnenykh zastarilymy pestytsydamy, ekolohichnoi ta kharchovoi bezpeky ta bezpeky dlia Pivdenno-Skhidnoi Yevropy ta Ukrainy. [Sustainable strategies of phytoremediation of the sites polluted with obsolete pesticides, Environmental and food safety and security for South-East Europe and Ukraine]. Springer-Verlag, New York, LLC, 81-89. [in Ukrainian].

4. Mokliachuk L., Drebot O., Mokliachuk O., Mokliachuk T. (2014) Ekolohichni ryzyky vid zabrudnennia ukrainskykh gruntiv stiikymy orhanichnymy zabrudniuvachamy. [Environmental risks of contamination of Ukrainian soil by persistent organic pollutants]. Doslidzhennia dovkillia ta ekolohii - Research into the environment and ecology 2 (1). 27-34. [in Ukrainian].

5. Mokliachuk L., Horodyska I., Slobodeniuk O., Petryshyna V. (2010) Fitoremediatsiia gruntu, zabrudnenoho zastarilymy pestytsydamy. Zastosuvannia fitotekhnolohii dlia ochyshchennia promyslovykh, silskohospodarskykh ta ochysnykh sporud [Phytoremediation of soil contaminated with obsolete pesticides. Application of phytotechnology for cleaning of industrial, agricultural and treatment facilities] 113-124. [in Ukrainian].

6. Yerina A.M. (2001). Statystychne modeliuvannia ta otsinky. [Statistical modeling and estimations]. Kyiv. [in Ukrainian].

7. Bethea, R., Duran, B. \& Boullion, T. (1985) Statistical Methods for Engineers and Scientists. New York, USA. Marcel Dekker, Inc [Statistical Methods for Engineers and Scientists]. New York: Marcel Dekker. [in English].

8. Aleksieieva I.V., Haidei V.O., Dikhovychnyi O.O., Fedorova L.B. (2011). Dyferentsialne obchyslennia funktsii kilkokh arhumentiv. Vyznacheni intehraly. Dyferentsialni rivniannia [Differential calculus of functions of several variables, methods of calculating a definite integral, systems of linear differential equations]. NTUU "KPI" . [in Ukrainian].

9. Prodanchuk M., Velykyi V., Kuchak Yu. (2003). Metodolohichni pidkhody do operatyvno-ekohihiienichnoi otsinky arealu ta obsiahu vykorystannia pestytsydiv u silskomu hospodarstvi v Ukraini [Methodological approaches to the operationalecological hygiene assessment of the range and volume of pesticide use in agriculture in Ukraine]. Navkolyshnye seredovyshhe ta zdorovya - Environment and health. 75 78. [in Ukrainian]. 
10. Aleksieieva I.V., Haidei V.O., Dikhovychnyi O.O., Fedorova L.B. (2011). Dyferentsialne obchyslennia funktsii kilkokh arhumentiv. Vyznacheni intehraly. Dyferentsialni rivniannia [Differential calculus of functions of several variables, methods of calculating a definite integral, systems of linear differential equations]. NTUU “KPI" . [in Ukrainian].

11. Prodanchuk M., Velykyi V., Kuchak Yu. (2003). Metodolohichni pidkhody do operatyvno-ekohihiienichnoi otsinky arealu ta obsiahu vykorystannia pestytsydiv u silskomu hospodarstvi v Ukraini [Methodological approaches to the operationalecological hygiene assessment of the range and volume of pesticide use in agriculture in Ukraine]. Navkolyshnye seredovyshhe ta zdorovya - Environment and health. 75 78. [in Ukrainian].

12. Solomon A.M., Vishtak I.V., Voitsitska O.M., Bondar M.M. (2018). Kharchovi dobavky ta yikh funktsionalna rol. [Nutritional supplements and their functional role]. Zbirnyk naukovykh prats VNAU.Ahrarna nauka ta kharchovi tekhnolohii - Collection of scientific works of VNAU. Agrarian science and food technologies . 4. 147-157. [in Ukrainian].

\section{АНОТАЦІЯ \\ ХАРАКТЕРИСТИКА РИЗИКУ - ЧЕТВЕРТИЙ ЕТАП ОЦНКИ ЕКОЛОГІЧНИХ РИЗИКІВ}

Значення ризику були отримані за допомогою моделі ситуащійного ризику, яка дає змогу визначити сховища (об'єкти) на територіях, де слід вжити спеціальних заходів для зменшення та ліквідащії забруднення. Результати досліджень чітко підтверджують наявність важких місцевих джерел забруднення сільськогосподарських угідь хлорорганічними пестицидами. Існує ризик забруднення інших об'єктів навколишнього середовища небезпечними речовинами та негативний вплив токсичних речовин на здоров'я людини. Виявлено міграцію пестицидів із трунту на сільськогосподарську продукцію та питну воду. На етапі характеристики ризику оиінюється частота та величина токсичних ефектів, їх зворотність чи незворотність. Одним із застосовуваних методів є метод порівняння отриманих результатів за аналогічними проектами та дослідженнями.

Важливою умовою впровадження загального землеробського використання територій у зонах, щзо постраждали від непридатних пестицидів та агрохімічних сховищ у иих населених пунктах, є пошук методів відновлення та очищення трунтів изих територій від ксенобіотиків. Лише після проведення робіт з очищення трунтів та наявності результатів перевірок, що показують позитивні зміни, де можна буде безпечно вирощувати сільськогосподарську продукиію.

Ключові слова: пестищиди, математична модель, сховища, небезпечний.

Табл. 2. Рис. 1. Літ. 12. 


\section{АННОТАЦИЯ \\ ХАРАКТЕРИСТИКА РИСКА - ЧЕТВЕРТЫЙ ЭТАП ОЦЕНКИ ЕКОЛОГИЧЕСКИХ РИСКОВ}

Значение риска были получены с помощью модели ситуаџионного риска, которая позволяет определить хранилища (объекты) на территориях, где следует принять специальные меры для уменьшения и ликвидации загрязнения.

Результаты исследований четко подтверждают наличие тяжельх местных источников загрязнения сельскохозяйственных угодий хлорорганическими пестицидами. Существует риск загрязнения других объектов окружающей среды опасными веществами и негативное влияние токсических веществ на здоровье человека. Выявлено миграцию пестицидов из почвы на сельскохозяйственную продукиию и питьевую воду.

На этапе характеристики риска оценивается частота и величина токсических эффектов, их обратимость или необратимость. Одним из применяемых методов является метод сравнения полученных результатов $с$ аналогичными проектами и исследованиями.

Важным условием внедрения общего земледельческого использования территорий в зонах, пострадавших от бывших пестииидов и агрохимических хранилищ в этих населенных пунктах, является поиск методов восстановления и очистки почв этих территорий от ксенобиотиков. Только после проведения работ по очистке почв и наличия результатов проверок, которые показывают положительные изменения, можно будет безопасно выращивать сельскохозяйственную продукиию.

Ключевые слова: устаревшие пестициды, математическая модель, склады, опасный.

Табл. 2. Рис. 1. Лит. 12.

\section{Інформація про автора}

Монарх Вероніка Валентинівна - канд. с.-г. наук, старший викладач кафедри лісового, садово-паркового господарства, садівництва та виноградарства Вінницького національного аграрного університета (21008, м.Вінниця, вул. Сонячна 3. e-mail: monarhinya@ukr.net).

Монарх Вероніка Валентинівна - кандидат сільськогосподарських наук, старший викладач кафедри садово-паркового господарства, садівництва та виноградарства Вінницького національного аграрного університету (21008, м. Вінниця, вул. Сонячна, 3, e-mail: monarhinya@ukr.net).

Monarkh Veronika - Candidate of Agricultural Sciences, Senior Lecturer of the Department of Landscape Management, Forestry, Horticulture and Viniculture of Vinnytsia National Agrarian University (21008, Vinnytsia, Soniachna Str., 3). 